\title{
Applied meiobenthos and nematode communities as tool for environmental monitoring and assessment in the Mekong estuarine system
}

\author{
Áp dụng quần xã động vật đáy cõ̃ trung bình và tuyến trùng nhu là công cu cho \\ quan trắc và đánh giá môi trường cửa sông Cưu Long \\ Review paper
}

Ngo, Xuan Quang ${ }^{1}$; Nguyen, Xuan Dung ${ }^{2}$; To, Thuy Nga ${ }^{3}$

${ }^{1}$ Institute of Tropical Biology, Vietnam Academy of Science and Technology, 85 Tran Quoc Toan Str., District 3, Ho Chi Minh City, Vietnam; ${ }^{2}$ Vietnam Biodiversity Conservation Agency, Vietnam Environment Administration; ${ }^{3}$ Administrative Office, Vietnam Environment Administration, Vietnam Ministry of Natural Resources and Environment

\begin{abstract}
The Mekong estuarine system is a sensitive ecosystem strongly affected by the economic activities in the region. This ecosystem is not only impacted by anthropogenic factors but is also known as one of the most severely affected areas by climate change. The environmental management in this estuarine system is very important and necessary. Many coastal provinces in the Mekong Delta have shown awareness of environmental estuarine management and set up bio-monitoring programs for water and ecological quality. However, meiobenthos and nematode communities were not yet included in environmental bio-monitoring while they are clearly proven to be a helpful bioindicator. This paper focuses on the obvious issue of using meiobenthos and nematode communities in this region as we recommend applying nematode and meiobenthos communities for environmental bio-monitoring and bio-management in the Mekong estuarine area.
\end{abstract}

Hệ thống cưa sông Cưu Long là vùng sinh thái nhạy cảm và đang chịu tác động mạnh mẽ tù các hoạt động kinh tế ven biển của các tỉnh miền Tây Nam Bộ. Hệ sinh thái khu vực này không nhũng bị ảnh hưởng trực tiếp tù con ngườ mà còn được biết đến nhu một trong nhũng khu vưc bị tác động nặng nề bởi biến đổi khí hậu. Vấn đề về quản lý môi trương ở hệ thống cưa sông này đã hết sức cần thiết. Các tỉnh trong khu vưc ven biển đồng bằng Sông Cửu Long cũng đã ý thức được tính nguy cấp trong công tác quản lý môi trường cưa sông ven biển và xây dụng các chuơng trình quan trắc chất luợng nước và hệ sinh thái. Tuy nhiên, hầu nhu chua có tỉnh nào ven biển đồng bằng sông Cưu Long đưa động vật đáy, đặc biệt là tuyến trùng vào các chuoong trình quan trắc và giám sát môi truòng trong khi các công trình nghiên cứu trên thế giới đã chứng minh khả năng chỉ thị chính xác của chúng. Bài viết phân tích cơ sở, các số liệu động vật đáy cõ trung bình và tuyến trùng khuyến nghị đưa vào công tác giám sát, quản lý môi trương cưa sông ven biển đồng bằng sông Cưu Long.

Keywords: environmental monitoring, nematode communities, meiobenthos, Mekong estuarine system

\section{Introduction}

The Mekong estuarine system is very sensitive and at the same time seriously affected at particular locations. This estuarine system plays an important role in the economic development of the region but also serves as the habitat for a variety of specialized fauna and flora. Moreover, this vulnerable delta is going to be affected by climate change
(Vietnam ranks among the top five most impacted countries in the world, UNDP (2012)), by seawater level and by the increase in accumulation of anthropogenic disturbance, the Mekong delta is facing many risks of serious impacts. It suffers directly from economic activities from the Mekong Delta region where many transportation, seaport activities, irrigation dam construction, aquaculture, agriculture activities as well as sea - production 
manufactories are taken place. Therefore, this area requires more scientific attention to have suitable mitigation solutions.

Several provinces in the Mekong estuarine system have shown interest for the protection of the ecological system by implementing different environmental monitoring programs. However, there is no official program available that makes use of zoobenthic fauna to detect changes in the ecological quality.

\section{Meiobenthos as tool for ecological assessment}

\subsection{Meiobenthos communities for ecological quality assessment}

Meiobenthos was regarded by many researchers as a tool for ecological assessment and environmental monitoring (Sergeeva and Mikhailova 1989a,b; Sergeeva 1992, Kennedy and Jacoby 1999; Fabiano et al. 2004; Vassallo et al. 2005, Alves et al 2013), based on the facts that they reflect changes occurring in the trophic state of benthic ecosystems, but also supported by their direct benthic development, their sessile life habit, their high species diversity, their short generation time, and their ubiquitous distribution. They are particularly important in estuaries as they continually rework the sediments and may alter the physical, chemical and biological characteristics of the estuary floor (Deeley and Paling, 1999). Since estuaries usually support important economic activities and show high densities of traffic routes, they are often massively affected. Smol et al (1994) showed how meiofauna of the Oosterschelde estuary was affected because of anthropogenic hydrodynamic changes, by decreasing the diversity but increasing the overall biomass.

Especially, nematode communities were often considered for ecological quality assessment and environmental monitoring. Heip et al. (1985) recommended the use of nematode (and meiofauna in general) as possible tool for detecting pollution. Marine nematodes have been suggested as potential pollution indicators as they possess some particular characteristics such as a short life-span and a high diversity (Heip, 1980). Tools that were commonly used in the past with meiofauna as pollution indicators are the nematode: copepod ratio, diversity indices or graphical methods ( $\mathrm{K}$ dominance curve) for representing the biodiversity, biomass spectra (Lambshead et al. 1983; Vanaverbeke et al, 2003), the Maturity index (Bongers et al., 1991) and Bongers (1999) or multivariate community analysis from a lower to a higher taxa level (Heip et al., 1985).

Nevertheless, Coull (1999) also mentioned that using molecular biotechnique to assess genetic diversity of meiobenthos and nematodes also provided a good tool for recognizing polluted sites in ecology and for environmental surveillance since polluted areas may show less genetic diversity (Street and Montagna, 1996). There are also some molecular approaches for meiobenthos in pollution assessment studies by using the polymerase chain reaction (PCR) technique, sequencing and cloning (Bhadury et al.,
2006; Ekschmitt and Korthals, 2009). Genomic changes may be directly attributable to a toxicant since they affect the genetic structure to develope mutations (Coull, 1999; Menzel et al., 2009). Since meiobenthos have a short generation time and since their association with bottom sediment environment where usually toxic substrates are usually deposited, they may response quickly to impacts. Therefore, these techniques are feasible to apply for environmental research on meiobenthos, particular nematodes due to their culturability, short generation time and large population sizes (Chandler et al., 1994; Coull, 1999). Hence, meiofauna and nematode can be introduced as very useful bio-assessors for risks in the estuarine environment (Bhadury et al., 2006).

\subsection{Meiobenthos assemblages interacting with their environment in Mekong estuarine system}

In addition, meiobenthos and free living nematode in the Mekong estuarine system were full investigated by Ngo et al (2010, 2011, 2013). Ngo (2012) provided full baseline data of meiobenthos communities and also pointed that nematode communities are very helpful for environmental biomonitoring in the Mekong estuaries. In this work, the composition of the meiobenthos in the Mekong estuaries was represented by 22 taxa in total from both seasons. In the wet season, 13 taxa of meiobenthos were found in this mainly marine habitat. In the dry season, 21 taxa of meiobenthos were found along the 8 Mekong estuaries. The composition of meiobenthos in dry season included some freshwater taxa such as aquatic insect larvae as Diptera, Coleoptera and Trichoptera. Some other taxa were also not found at the mouth stations in the rainy season such as Isopoda, Sycarida, Acarida, Kinorhyncha, Decapoda, and Tanaidacea. Nematodes always have the highest percentage in the meiobenthos communities (from 64\% - 99\% in the wet season and 40 to $98 \%$ in the dry season).

Ngo (2012) also reported that densities of meiobenthos in the Mekong estuaries were found to be quite high with values from $581-3,168$ individuals $/ 10 \mathrm{~cm}^{2}$ in the wet season and from $105-3,678$ individuals $/ 10 \mathrm{~cm}^{2}$ in the dry season. Moreover, meiobenthic fauna assemblages in the Mekong estuaries were investigated due to its high diversity, high densities and high dominance of nematodes in all stations. Meiobenthos can survive over a wide salinity range and are well adapted to the estuarine area so they can be a suitable organism for environmental researches.

Furthermore, meiobenthos was also studied with the specific environmental conditions of the Mekong estuarine system. The composition of meiobenthic communities was considered to be influenced by grain size, dissolved oxygen, coliform densities and ammonium concentration in the sediment. Especially, the diversity of meiobenthos was found to become lower when chlorophyll $a$ increased while their densities increased. In this estuarine system, chlorophyll $a$ seems to have closer relationship with the composition of the meiobenthos. However, food was rarely considered to be a limiting factor for meiobenthic life in brackish silty sediment habitats because of their typical rich content of organic matter (Giere, 2009) but 
chlorophyll a seems highly influential to densities and diversity of meiobenthic animals in this estuarine system.

\subsection{Nematode communities interacting with their environment in Mekong estuarine sys- tem}

Specifically, nematode communities in the Mekong estuarine system were also investigated in detail by $\mathrm{Ngo}$ (2012). In total, there were 244 genera, 59 families, 11 orders of 2 classes Enoplea and Chromadorea of phylum Nematoda present in the whole estuarine system. The composition of nematode communities was a mix between marine and freshwater taxa. The study also indicated that nematode diversity in the Mekong estuaries was quite high. Moreover, the nematode size and shapes were also investigated to detect the relationships with other nematode characters such as feeding types and ecological features.

Moreover, database of nematode communities were also added in correlation with other environmental parameters of Mekong estuaries in order to find out which factors influence the communities structure. The baseline database showed that the nematode communities were strongly correlated with grain size, dissolved oxygen, coliform and chlorophyll $a$ concentration. Especially, grain size, dissolved oxygen and chlorophyll $a$ could be linked to the presence of two to four different nematode communities each with different characters which were identified based on the dominant genera used as a major representative for the groups. The group of Desmodora communities and the group of Oncholaimellus - Desmodora communities were mainly found in sandy sediments; the group Parodontophora - monhysterid and Parodontophora communities were found in silty sand habitats. This association of specific nematode communities as identified based on the dominant genera was also related to the feeding ecology.

According to Wieser (1953, 1959), deposit feeders are usually found in mud or silty sand which is similar to our observation of the monhysterid group. In addition, the groups of Oncholaimellus - Desmodora communities dominated by carnivores, omnivores and epistrate feeders often occupy coarse sand, with a low organic content. The ecology of nematode feeding types was further investigated and adapted by Traunspurger (1997), Moens and Vincx (1997), and Moens et al. (2006). The nematode feeding activity is affected by a variety of environmental factors, especially substrate characteristics such as sediment texture and pore size may affect the activity of both consumers and resources (Moens et al., 2006).

This study also delivered an insight into the link between nematode size and shape with other specific modes of life, or ecological interactions in terms of feeding types, densities and diversity of nematode communities as well as environmental factors. The nematodes with long bodies occupy a higher proportion in sandy stations where chlorophyll $a$ concentration is rather low than in silty sediments with high chlorophyll $a$ concentration. It also seems that mainly predators/carnivorous are better represented in sandy sediments whereas silty sediments are better suited for deposit feeders. The percentage of silt in the sediment increases together with the chlorophyll $a$ concentration in association with high proportions of short and small deposit feeding nematodes which showed in general a low maturity index.

Furthermore, the baseline study also considered the seasonal trend in the Mekong estuarine nematode communities. A comparison was made for most of the measured features of nematode communities between dry season and wet season. The results showed that the variation only occurred in limited stations, there were no differences in densities between seasons. The biodiversity calculated in the Shannon - Wiener index showed slightly higher values in the dry season. In general the structure at a spatial scale was larger than at a seasonal scale. The high spatial variation was explained by sediment features as they mainly controlled the nematode communities.

\section{Environmental biomonitoring in the Mekong estuarine system by using nematode and meiobenthos communi- ties}

According to Ritz et al. (2009), there are among 183 bioindicator candidates in soil, nematodes were found as a powerful bioindicator for environmental monitoring. Due to the advantages by the ecological characteristics of nematode such as being ubiquitous, sensitive, having a high abundance and high biodiversity in the estuarine system, the nematode communities in the Mekong estuarine system can play a very important role in order to reflect the ecological conditions. From Ngo (2012), the nematode communities were intensively investigated in terms of community structure and distribution, morphometry and biomass in relationship with the environmental conditions of this area. In this respect, it provided a full baseline data for future community changes in relation to changing environmental conditions.

In the estuarine ecosystem, chemical substrates get into the water and sink down, mixing with bottom sediment where they become a pollutant in the benthic food chain, which also affects higher trophic levels. Contrary to chemical factors which are changing very fast in nature, the biological impact can prolong the disturbance effect of pollutants on ecosystem functions. Nematodes are the most dominant taxon of the benthic metazoans. They usually live closely associated with sediment conditions where their permeable cuticles provide direct contact with their microenvironment so they respond rapidly to the disturbance. Moreover, nematodes cannot migrate fast under stressing conditions (Bongers and Ferris, 1999) so their community's features can provide us an indication of the environmental quality based on analyzing together the environmental variables and nematodes communities.

In Ngo (2012), univariate and multivariate analysis were applied and the author found out that nematodes' characters and community's structure showed to a great extent the ecological conditions in the Mekong estuarine area. The univariates included densities and biodiversity indi- 
ces. The maturity index based on c-p values also represented to some extent information about environmental conditions. It is also suggested using the trophic structure based on nematode feeding types since they reflected ecological features such as nematode biomass, size and shape. Beside univariate measures, the multivariates analysis will provide a maximum on information.

Moreover, since the seasonal variation in nematodes' communities in the Mekong estuarine area is rather low, it supports the idea of using them as bioindicator for environmental monitoring.

Other advantages of using nematode as a tool for environmental monitoring in the Mekong delta is that they are very easily sampled and sorted. This tool is not only suitable, it is also a cheap and feasible strategy in a developing country such as Vietnam. Therefore, the nematode identification regarding genus (or family level) as a tool can be easily tought to environmental officers in regional provinces. The nematode monitoring can also be provided as a tool for the Mekong River Committee to establish an environmental monitoring program, which supports the regional sustainable development in relation to the intensive aquaculture and agricultural activities.

\section{Recommendation}

Therefore, it is recommended that nematodes can be used as a bioindicator to provide a powerful tool in environmental monitoring programs in the Mekong estuaries. It can be suggested as the NEMA - TOOL in the environmental monitoring system for both national and international programs of The Mekong River Commission.

\section{References}

[1] Alves A.S., Adão H., Ferrero T.J., Marques J.C., Costa M.J., Patrício J. 2013. Benthic meiofauna as indicator of ecological changes in estuarine ecosystems: The use of nematodes in ecological quality assessment. Ecological Indicators 24: 462-475

[2] Bhadury P., Austen M.C., Bilton D.T., Lambshead P.J.D., Rogers A.D., Smerdon G.R. 2006. Molecular detection of marine nematodes from environmental samples: overcoming eukaryotic interference. Aquatic Microbial Ecology 44: 97-103

[3] Bongers T. 1999. The Maturity Index, the evolution of nematode life history traits, adaptive radiation and cp-scaling. Plant and Soil 212: 13-22

[4] Bongers T., Alkemade R., Yeates G.W. 1991. Interpretation of disturbance-induced maturity decrease in marine nematode assemblages by means of the Maturity Index. Marine Ecology Progress Series 76: $135-142$

[5] Bongers T., Ferris H. 1999. Nematode community structure as a bioindicator in environmental monitoring. Trends in Ecology \& Evolution 14: 224-228

[6] Chandler G.T., Coull B.C., Davis J.C. 1994. Sediment- and aqueous-phase fenvalerate effects on meiobenthos implications for sediment quality criteria development. Marine Environmental Research 37: 313-27

[7] Coull B.C. 1999. Role of meiofauna in estuarine soft-bottom habitats. Australian Journal of Ecology 24: $327-343$

[8] Deeley, D.M., Paling E.I. 1999. Assessing the ecological health of estuaries in Australia, National River Health Program, Urban Sub Program, Report No.10, LWRRDC Occasional Paper 17/99

[9] Ekschmitt K., Korthals G. 2009. Molecular markers, indicator taxa, and community indices: the issue of bioindication accuracy. In: Wilson M.J., KakouliDuarte T. (eds) Nematodes as environmental indicators. CABI Publishing, Wallingford, $326 \mathrm{pp}$

[10] Fabiano, M., Vassallo, P., Vezzulli, L., Salvo, V.S., Marques, J.C. 2004. Temporal and spatial change of exergy and ascendency in different benthic marine ecosystems. Energy 29: 1697-1712

[11] Giere, O. 2009. Meiobenthology. The microscopic motile fauna of aquatic sediments. 2nd edition. Springer Verlag, Heidelberg. 527 pp

[12] Heip, C. 1980. Meiobenthos as a tool in the assessment of marine environmental quality. Rapports et Proces-Verbaux des Reunions Monaco 179: 182-187

[13] Heip, C., Vincx, M., Vranken, G. 1985. The ecology of marine nematodes. Oceanography and Marine Biology: An Annual Review 23: 399-489

[14] Kennedy, A.D., Jacoby, C.A. 1999. Biological indicators of marine environmental health: Meiofauna A neglected benthic component. Environmental Monitoring and Assessment 54: 47-68

[15] Lambshead, P.J.D., Platt, H.M., Shaw, K.M. 1983. Detection of differences among assemblages of marine benthic species based on an assessment of dominance and diversity. Journal of Natural History 17 : 859-874

[16] Menzel, R., Steinberg, C.E.W., Stürzenbaum, S.R. 2009. Caenorhabditis elegans and chemical environmental stressors: from DNA microarrays and data analysis to genomic data of true ecotoxicological relevance. In: Wilson M.J., Kakouli-Duarte T. Nematodes as environmental indicators. CABI Publishing, Wallingford, $326 \mathrm{pp}$

[17] Moens, T., Bergtold, M., Traunspurger, W. 2006. Feeding ecology of free-living benthic nematodes. In: Eyualem-Abebe E., Traunspurger W., Andrássy I. (eds.) Freshwater nematode: Ecology and Taxonomy. The CABI Publishing. 752p

[18] Moens T., Vincx, M. 1997. Observations on the feeding ecology of estuarine nematodes. Journal of Marine Biological Association of the United Kingdom 77: 211-227

[19] Ngo, X.Q. 2012. Ecology of free living marine nematodes in the Mekong estuaries. Vietnam. $294 \mathrm{pp}$, ISBN: 9789090271422

[20] Ngo, X.Q., Nguyen, N.C., Nguyen, V.T., Vanreusel A., Smol N. 2011. The composition and diversity of 
nematode community in the Mekong estuarine system. Vietnam National Conference on Ecology and Biological Resources 4: 824-831

[21] Ngo, X.Q., Smol, N., Vanreusel, A. 2013. The meiofauna distribution in correlation with environmental characteristics in 5 Mekong estuaries, Vietnam. Cahiers de Biologie Marine, 54-1

[22] Ngo, X.Q., Vanreusel, A., Smol, N., Nguyen, N.C. 2010. Meiobenthos in the Mekong estuarine system with special focus on free living marine nematodes. Ocean Science Journal 45: 213-224.

[23] Ritz, K., Black, H.I.J., Campbell, C.D., Harris, J.A., Wood, C. 2009. Selecting biological indicators for monitoring soils: A framework for balancing scientific and technical opinion to assist policy development. Ecological Indicators 9: 1212-1221

[24] Sergeeva, N.G. 1992. The characteristics of the freeliving nematode fauna of Jalta gulf under anthropogenic impact. In: Zaika V.E. (eds) Long-term changes of zoobenthos in the Black Sea. Naukova Dumka Publishing, Kiev, pp. 170-184

[25] Sergeeva, N.G., Mikhailova, T.V. 1989a. Distribution and structure of bottom communities in Jalta gulf. "VINITI" Publ., Moscow. \#1328-B89, 12 pp

[26] Sergeeva, N.G., Mikhailova, T.V. 1989b. Distribution and structure of bottom communities in some regions of the Southern coast of Crimea. "VINITI" Publ., Moscow \#1329-B89, 8 pp

[27] Smol, N., Willems, K.A., Govaere, J.C., Sandee,
A.J.J. 1994. Composition, distribution and biomass of meiobenthos in the Oosterschelde estuary SW Netherlands. Hydrobiologia 282/283: 197-217

[28] Street, G.T., Montagna, P.A. 1996. Loss of genetic diversity in Harpacticoida near offshore platforms. Marine Biology 126: 271-282

[29] Traunspurger, W. 1997. Bathymetric, seasonal and vertical distribution of feeding-types of nematodes in an oligotrophic lake. Vie et Milieu 47: 1-7

[30] UNDP (2012). http://www.undp.org.vn/ (retrieved on 25.11.2013)

[31] Vanaverbeke, J., Steyaert, M., Vanreusel, A., Vincx, M. 2003. Nematode biomass spectra as descriptors of functional changes due to human and natural impact. Marine Ecology Progress Series 249: 157-170

[32] Vassallo, P., Fabiano, M., Vezzulli, L., Sandulli, R., Marques, J.C., Jørgensen, S.E. 2005. Assessing the health of coastal marine ecosystems: A holistic approach based on sediment micro and meio-benthic measures. Ecological Indicators 6: 525-542

[33] Wieser, W. 1953. Die Beziehung zwischen Mundhöhlengestalt, Ernährungsweise und Vorkommen bei freilebenden marinen Nematoden: eine ökologisch-morphologische Studie. Arkiv för zoologi 4: 439-484.

[34] Wieser W. 1959. Free-living nematodes and other small invertebrates of Puget Sound beaches. I. Florida. Bulletin of the Museum of Comparative Zoology 135: $239-344$ 